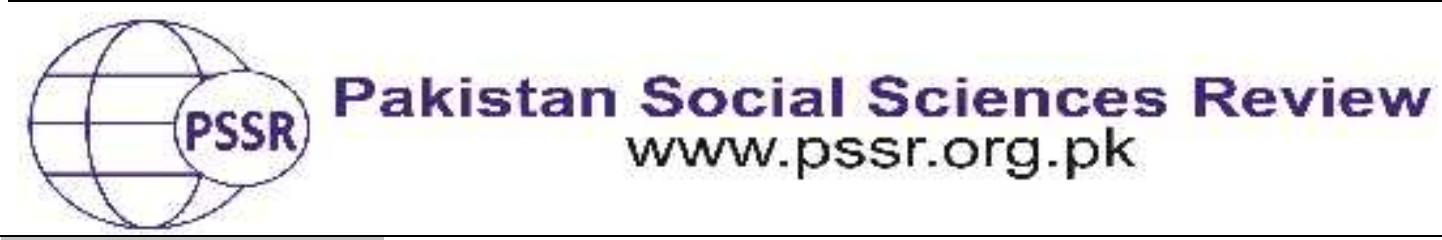

RESEARCH PAPER

\title{
Determinants of Participation of Women to Paid Labor Market Work and Unpaid Household Work
}

\author{
Sidra Yaqoob ${ }^{1}$ Amtul Hafeez ${ }^{2}$
}

1. PhD Scholar, Department of Economics, National University of Modern Languages, Islamabad, Pakistan

2. Assistant Professor, Department of Economics, National University of Modern Languages, Islamabad, Pakistan

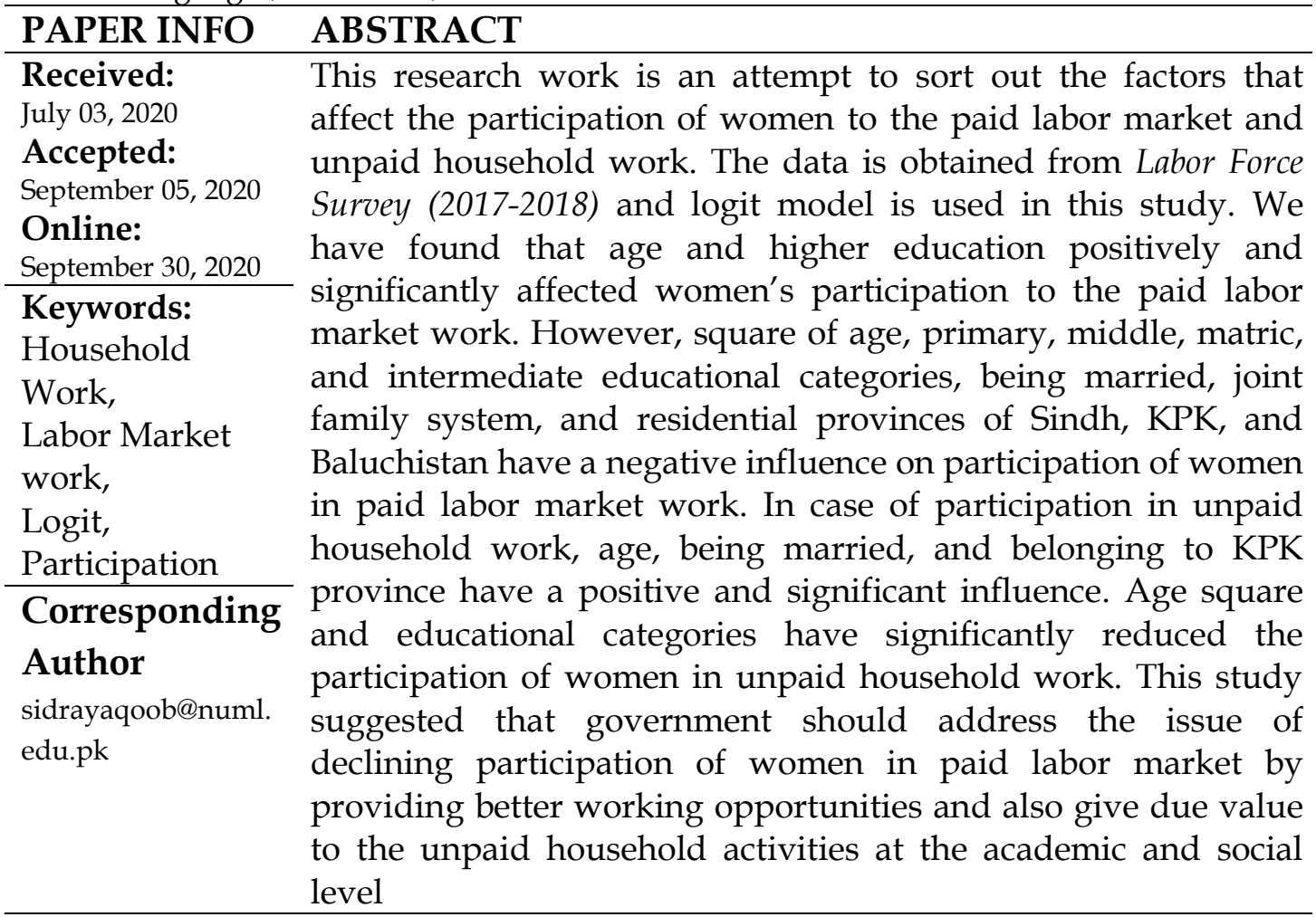

\section{Introduction}

There are numerous economic and non-economic factors that influence pattern of participation of individuals and households to market and non-market work, Kes and Swaminathan (2006). And, it has become important matter of concern in last few decades among the researchers. Initially, the major focus of studies is on the determinants of participation to market work and as a result, great amount of literature is known on market's participation behavior. In contrary, how household participate within the home has largely been ignored and as a result little is known household's participation behavior. The pioneering work of Becker and Gronau were the first in this field. And, as a result increasingly attempts are being made with 
the passage of time to the analysis of the participation and time allocation behavior of household within the home, Khandker (1988).

In a developing country, like Pakistan, in which women make a half of the population of our country, but their contribution in labor market is much lower. According to the Labor Force Survey (2017-2018) of Pakistan, the rate of women's labor force participation (WLFP) is 22.8 percent. There are a number of economic and non-economic factors in our country that hinders women's participation in labor market. Therefore, in this paper, an attempt is made to sort out the factors that influence the participation of women in labor market.

Another important area for households is the unpaid household work. Majority of the women whether employed and unemployed do participate and spend large amount of time on the household work. Participation and allocating time to the unpaid household work is an important resource for household. For example, if the household member brings water from the nearest stream instead of instead of water supplied through the pipe, which is paid one, they are basically saving money. Similarly, women that are involved in educating activities of children, poultry raising, and maintaining home etc., saves the amount of money that she spends if she hired these services. Although, all of these unpaid activities are the basic needs, but these are not recorded and shown in official data, thus, ignoring the importance or value of the efforts of women in this regard at the national accounts, Illahi (2000). The services provided by women in making home heaven have largely been ignored in our society and is taken for granted in making policy, Beneria (2003). It is the time to recognize the value of these unpaid services of women by counting them at the national accounts and at the academic level.

Therefore, the focus of our study is to investigate the numerous determinants that have an important bearing with the decision of women to participate in paid labor market and unpaid household work. There is no study in our country that has determined the determinants of participation of women in household work that is unpaid. Secondly, no study has been done so far in our country that has used the Labor Force Survey (2017-2018)data for the determinants of paid labor market and unpaid household work. By keeping this, there are two main aims of our study. First, is to examine the determinants of participation to the paid labor market work. And, the second aim is to examine the determinants of participation to unpaid household work.

\section{Literature Review}

The study of determinants of women's participation to paid labor market and unpaid household activities has gained substantial attention in the developed and especially developing countries in recent years. The pioneering work regarding the household behavior of participation and time allocation to the paid market and unpaid non-market work was of Becker (1965) and Gronau (1977). With the passage of time, an immense number of studies examined the determinants of participation 
and time allocation to market and household work at the national and international level. Therefore, this section presents the review of studies on the determinants of market and household work.

According to the studies of Chishti et al. (1989) and Kozel and Alderman (1990), level of education, wage rate, and expected earnings positively affected the labor force participation. Presence of male family member significantly reduced WLFP, however, presence of female family member significantly increased WLFP in labor market.

Hafeez and Ahmed (2002) concluded that education, age, household size and structure have a positive association with WLFP in labor market. On the other hand, financial assets, household's monthly income, and availability of other working members in family negatively affected WLFP in labor market. According to Farid et al. (2009), household assets, spouse participation in earning activities, and younger children in family have reduced WLFP. However, variables like marital status, education, educated husband, number of children, and family setup have significantly increased WLFP.

Hosney (2016) analyzed the dynamics of women's participation in labor force in Egypt. The study concluded that age and education have significantly increased the WLFP. On the other hand, number of children, being married and urban location has significantly reduced the WLFP. Household size and relation to household have an insignificant relationship with WLFP. According to the study of Che and Sundjo (2018), increment in level of education, being Muslim and presence of small children of age 0-5 years have a negative and significant influence on women labor force participation. Being married, non-working husband, and increase in age are positively related with WLFP.

Singh and Pattanaik (2019), investigated the factors of participation of women in paid and unpaid work. According to the study, married women have a higher probability of participation in unpaid work and unmarried women have a higher probability of participation in paid work. Females belonging to poor background and possesses lower education are major determinants that involve females in unpaid work.

Kanwal et al. (2019) examined the determinants of working hours of males and females by using Labor force survey (2010-2011) data from Pakistan. According to the study age, gender, numbers of siblings and education level have a positive influence on labor supply. Residential location, household size, and household head variables are negatively associated with working hours in labor market. Married workers work longer hours in labor market, but the coefficient is found to be statistically insignificant.

The study of Bianchi et al. (2000) found that presence of children in the home has increased the time both for men and women. More time spent on housework if there are younger children and reduction in time if there are older children. Aging 
factor shows that older members spent more time on housework as compared to the younger ones. Marital status has a positive effect on time allocated to housework by women but not for men. The more the women educated the less time they devote to housework. Amount of time allocated to the housework decrease if the women or wives are employed resulting in rise of husband's time for the housework and consequently reduction in gender gap. Income has a negative correlation with the time of the housework. Homeownership has also positively affected the time allocated to housework by both husbands and wives.

It has been observed that the women's' participation in the domestic work is higher as compared to the males. Age has a positive influence on participation of women in domestic work. Married women have a higher participation in the domestic work as compared to the singles. However, level of education significantly reduced the women's participation in domestic work, Kedir and Rogers (2018).

According to Tamene and Desta (2019), females have more burden of housework as compared to the males. The results of the study supported that probability of participation in domestic work has increased for married ones. In case of the unmarried ones, males have less involvement in the housework because females prefer to work by themselves. With the increase in the level of education, time for housework has declined and age also has a negative impact on the housework.

Thus, we have seen that a lot of work is done on the issue of determinants of participation to the paid market and unpaid household work at the international level. As far Pakistan is concerned, we have seen a substantial amount of work on participation of women in labor market work, i.e. Hafeez and Ahmad (2002);Faridi and Basit (2011); Faridi et al. (2009) to name a few. But no remarkable studies are seen on the determinants of participation in unpaid household work. Therefore, this study fills this literature gap by examining the determinants of participation to the paid labor market work and unpaid household work by using the data from Labor Force Survey (2017-2018), Pakistan.

\section{Material and Methodology}

The data of the study is obtained from the Labor Force Survey (2017-2018) of Pakistan. The total sample size of labor market work consists of 74,457 women of age 15-64 years. And, the total sample size of household work consists of 53,559women of age 10-64 years and this sample consisted of women that are not participating in paid labor market work. The description of all the dependent and independent variables of study is given in Table 1. 
Table 1

Description of Variables of Study

\begin{tabular}{ccc}
\hline Variables & Description & Measurement \\
\hline Dependent Variables & Participation in paid labor \\
market work & $\begin{array}{c}\text { WLFP is equal to 1 if } \\
\text { woman is involved in } \\
\text { paid labor market work } \\
\text { during a reference week } \\
\text { and 0 otherwise }\end{array}$ \\
\hline WHWP & $\begin{array}{c}\text { WHWP is equal to } 1 \text { if } \\
\text { Participation in unpaid } \\
\text { household work }\end{array}$ & $\begin{array}{c}\text { wompaid household work } \\
\text { during a reference week } \\
\text { and 0 otherwise }\end{array}$ \\
\hline
\end{tabular}

Independent Variables

\begin{tabular}{|c|c|c|}
\hline Age & Age & Age in completed years \\
\hline Age square & Age square & Square of age \\
\hline Primary & Primary education & $\begin{array}{c}\text { It is equal to } 1 \text { if the } \\
\text { woman has acquired } \\
\text { primary education andis } \\
0 \text { otherwise }\end{array}$ \\
\hline Middle & Middle education & $\begin{array}{l}\text { It is equal to } 1 \text { if the } \\
\text { woman has acquired } \\
\text { middle education and is } 0 \\
\text { otherwise }\end{array}$ \\
\hline Matric & Matric education & $\begin{array}{c}\text { It is equal to } 1 \text { if the } \\
\text { woman has acquired } \\
\text { matric education and is } 0 \\
\text { otherwise }\end{array}$ \\
\hline Intermediate & Intermediate education & $\begin{array}{l}\text { It is equal to } 1 \text { if the } \\
\text { woman has acquired } \\
\text { intermediate education } \\
\text { and is } 0 \text { otherwise }\end{array}$ \\
\hline Higher & Higher education & $\begin{array}{c}\text { It is equal to } 1 \text { if the } \\
\text { woman has acquired } \\
\text { either bachelor, master, } \\
\text { M. Phil or PhD and is } 0 \\
\text { otherwise }\end{array}$ \\
\hline Married & Marital status & $\begin{array}{l}\text { It is equal to } 1 \text { if the } \\
\text { woman is married and } 0 \text { if } \\
\text { woman is unmarried }\end{array}$ \\
\hline
\end{tabular}




\begin{tabular}{ccc}
\hline SC & Children & $\begin{array}{c}\text { Total number of small } \\
\text { children of age less than } \\
\text { equal to five years }\end{array}$ \\
\hline Joint & Type of family & $\begin{array}{c}\text { A value of } 1 \text { is assigned if } \\
\text { woman is from joint } \\
\text { family system and0 if in } \\
\text { nuclear family system }\end{array}$ \\
\hline KPK & Sindh & $\begin{array}{c}\text { A value of } 1 \text { is assigned if } \\
\text { woman belongs to the } \\
\text { Sindh province and0 } \\
\text { otherwise }\end{array}$ \\
\hline Baluch & KPK & $\begin{array}{c}\text { A value of } 1 \text { is assigned if } \\
\text { woman belongs to the } \\
\text { KPK province and } 0 \\
\text { otherwise }\end{array}$ \\
\hline$\mu_{1}$ & Baluchistan & $\begin{array}{c}\text { A value of } 1 \text { is assigned if } \\
\text { woman belongs to the } \\
\text { Baluchistan province } \\
\text { and } 0 \text { otherwise }\end{array}$ \\
\hline
\end{tabular}

Since, probability of participation is a binary variable and is equal to 1 if the woman is participating and 0 otherwise. That's why Logit model is used to determine the women's participation into paid labor market and unpaid household work. The model in general form is expressed as follows:

$$
Y_{i}=\beta X_{i}+\mu_{\mathrm{i}}
$$

Where $\beta$ is a row vector of parameters, $X_{i}$ is column vector of parameters, and $\mu_{\mathrm{i}}$ is error term which is normally distributed with mean zero. The logit model for the women's participation to the paid labor market work is given as follows:

$$
\operatorname{Ln}\left[\frac{P_{i}}{1-P_{i}}\right]=Y_{i}=\beta X_{i}+\mu_{i} 2
$$

The operational form of the logit model of women participation to the paid labor market work is given in equations 3 and 4 .

$$
\mathrm{WLFP}=\mathrm{f}\left[\begin{array}{c}
\text { Age, Agesquare, Primary, Middle, Matric, Intermediate, } \\
\text { Higher , Married, Number of small children, } \\
\text { Joint family, Sindh, KPK, Baluchistan }
\end{array}\right]
$$




$$
\begin{aligned}
\text { WLFP }=\beta+ & \beta_{1} \text { Age }_{i}+\beta_{2} \text { Agesquare }_{i}+\beta_{3} \text { Primary }_{\mathrm{i}}+\beta_{4} \text { Middle }_{\mathrm{i}}+\beta_{5} \text { Matric }_{\mathrm{i}} \\
& +\beta_{6} \text { Intermediate }_{\mathrm{i}}+\beta_{7} \text { Higher }_{\mathrm{i}}+\beta_{8} \text { Married }_{\mathrm{i}}+\beta_{9} \text { SC }_{\mathrm{i}}+\beta_{10} \text { Joint }_{\mathrm{i}} \\
& +\beta_{11} \text { Sindh }_{\mathrm{i}}+\beta_{12} \text { KPK }_{\mathrm{i}}+\beta_{13} \text { Baluch }_{\mathrm{i}}+\mu_{\mathrm{i}}
\end{aligned}
$$

Where WLFP indicates the participation of women to the paid labor market work. The logit equation for the women participation to the unpaid household work is given as follows:

$$
\operatorname{Ln}\left[\frac{P_{i}}{1-P_{i}}\right]=Y_{i}=\alpha X_{i}+\mu_{i} \quad 5
$$

The operational form of the logit model of women participation to the unpaid household work is given in equations 6 and 7.

$$
W H W P=f\left[\begin{array}{c}
\text { Age, Agesquare, Primary, Middle, Matric, Intermediate, } \\
\text { Higher , Married, Number of small children, } \\
\text { Joint family, Sindh, KPK, Baluchistan }
\end{array}\right] 6
$$

$$
\begin{aligned}
\text { WHWP }=\alpha+ & \alpha_{1} \text { Age }_{\mathrm{i}}+\alpha_{2} \text { Agesquare }_{\mathrm{i}}+\alpha_{3} \text { Primary }_{\mathrm{i}}+\alpha_{4} \text { Middle }_{\mathrm{i}}+\alpha_{5} \text { Matric }_{\mathrm{i}} \\
& +\alpha_{6} \text { Intermediate }_{\mathrm{i}}+\alpha_{7} \text { Higher }_{\mathrm{i}}+\alpha_{8} \text { Married }_{\mathrm{i}}+\alpha_{9} \text { SC }_{\mathrm{i}}+\alpha_{11} \text { Joint }_{\mathrm{i}} \\
& +\alpha_{12} \text { Sindh }_{\mathrm{i}}+\alpha_{13} \text { KPK }_{\mathrm{i}}+\alpha_{14} \text { Baluch }_{\mathrm{i}}+\mu_{\mathrm{i}}
\end{aligned}
$$

Where WHWP represents the women participation to the unpaid household work. Household work includes activities like agricultural operations, livestock operations, poultry raising, processing food, construction work, bringing water, collection firewood, cleaning and arranging house, making clothes, washing and pressing clothes, shopping, and cooking food, Bloemen and Stancanelli (2014).

\section{Empirical Results}

The mean and standard deviation of all underlying variables are given in Table 2. According to the descriptive statistics, women's participation to unpaid household work is higher as compared to the women that are participating to the labor market work. And, this is according to the expectations and reality. The characteristics that distinguish women who are working in market than those who are working only at home are more interesting and differ substantially between these two groups. Women that are participating in unpaid household work are younger to that women who are working in the labor market. Women that are participating in labor market production have higher years of schooling as compared to those who work only at home.

Women who are participating in labor market production are more married as compared to those who are participating in household production. This is reality that women whether married or unmarried have more responsibilities of household chores as compared to the labor market work. Percentage of women from larger household size and joint family system is slightly higher for household group that 
belongs to the labor market group. Women from Baluchistan have a higher percentage of participation in unpaid household work as compared to the paid labor market work. However, for all other provinces, women's percentage is almost equal for both of these groups.

Table 2

Descriptive Statistics

\begin{tabular}{|c|c|c|c|c|}
\hline \multirow{2}{*}{ Variables } & \multicolumn{2}{|c|}{ Paid labor market work } & \multicolumn{2}{|c|}{ Unpaid Household work } \\
\hline & Mean & $\begin{array}{l}\text { Standard } \\
\text { deviation }\end{array}$ & Mean & $\begin{array}{l}\text { Standard } \\
\text { deviation }\end{array}$ \\
\hline \multicolumn{5}{|c|}{ Dependent variables } \\
\hline WLFP & 0.781 & 0.414 & ........ & ....... \\
\hline HWP & $\ldots \ldots$ & $\ldots \ldots$ & 0.992 & 0.092 \\
\hline \multicolumn{5}{|c|}{ Independent variables } \\
\hline Age & 32.425 & 13.018 & 28.495 & 14.237 \\
\hline Age square & 1220.836 & 952.224 & 1014.694 & 955.554 \\
\hline Primary & 0.168 & 0.374 & 0.280 & 0.449 \\
\hline Middle & 0.129 & 0.335 & 0.116 & 0.321 \\
\hline Matric & 0.139 & 0.346 & 0.113 & 0.316 \\
\hline Intermediate & 0.068 & 0.252 & 0.055 & 0.228 \\
\hline Higher & 0.068 & 0.252 & 0.055 & 0.228 \\
\hline Married & 0.678 & 0.467 & 0.546 & 0.498 \\
\hline SC & 2.081 & 1.277 & 2.041 & 1.260 \\
\hline Joint & 0.979 & 0.144 & 0.979 & 0.145 \\
\hline Sindh & 0.215 & 0.411 & 0.218 & 0.413 \\
\hline KPK & 0.197 & 0.398 & 0.198 & 0.399 \\
\hline Baluch & 0.115 & 0.318 & 0.122 & 0.327 \\
\hline Sample size & 18,621 & & 53,559 & \\
\hline
\end{tabular}

Estimates of Determinants of Participation of Women to the Paid Labor Market Work

The results of the estimates of WLFP to the paid labor market are given in Table3. According to the logit model, age has a positive and age square has a negative and statistically significant influence on the WLFP to the labor market. This implies that WLFP is lower at the younger age because of lack of mandatory qualification, experience, and skills. But, as the age increases, women's probability of participation to the labor force increases because they equip themselves with better education, experience, and skills. However, at the older age women's probability of participation to the labor force decreases due to lack of energy and deteriorating health conditions, Hafeez and Ahmed (2002); Hussain et al. (2016); Batool et al. (2019). 
Another important determinant of WLFP is education. The results revealed that regression coefficients of primary, middle, matric, and intermediate educational categories are negative and statistically significant. This means that up to the intermediate level, educated women have a lower probability of participation to the labor market with those of women having no formal education, Hussain et al (2016); Khan and Hafeez (2017) and Che and Sundjo (2018). This may be because higher level of education is an indication that women are not from a poor family background. They belong to the families that at least hope that their women would get either better job or otherwise no job. On the other hand, women that are not highly educated or no education at all have to participate in paid labor market for the survival and to be independent, Khan and Khan (2009). However, the regression coefficient of higher educational category is positive and statistically significant, which means that highly educated women have a higher LFP with those of women having no formal.

As far marital status is concerned, it has been observed that married women are less likely to join labor market as compared to the unmarried ones, Chishti et al. (1989); Batool et al. (2019). This is because of the more burdens of household chores on married women as compared to unmarried ones. Presence of small children are found to be negatively but insignificantly related with WLFP in labor market. Women living in joint family have a lower probability of participation in labor market work than women from the nuclear family system, Ejaz (2007). One possible reason of this may be the increased burden of household chores of large family. Another possible reason may be the presence of other family members who reduce and share the financial needs of the family.

It has been observed that the women from Sindh, KPK, and Baluchistan have a lower LFP in labor market to that of women from the Punjab. This may be due to fact that better employment opportunities are prevailing in Punjab to that of other provinces of Pakistan, Hussain et al. (2016).

Table 3

Estimates of Determinants of Women's Participation to the Paid Labor Market Work

\begin{tabular}{ccc}
\hline Explanatory Variables & $\begin{array}{c}\text { Coefficients and } \\
\text { t-values }\end{array}$ & Marginal Effects \\
\hline \multirow{2}{*}{ Constant } & $-1.308^{* * *}$ & \\
\hline \multirow{2}{*}{ Age } & $(-8.65)$ & $0.015^{* * *}$ \\
& $(12.74)$ & $-0.008^{* * *}$ \\
\hline \multirow{2}{*}{ Agesquare } & $-0.001^{* * *}$ & $(-12.50)$ \\
\hline \multirow{2}{*}{ Primary } & $(-12.45)$ & $-0.092^{* * *}$ \\
Middle & $-0.743^{* * *}$ & $(-22.28)$ \\
\hline \multirow{2}{*}{ Midd } & $(-18.31)$ & $-0.147^{* * *}$ \\
& $-1.491^{* * *}$ & $(-39.14)$ \\
\hline
\end{tabular}




\begin{tabular}{ccc}
\hline Matric & $-1.487^{* * *}$ & $-0.147^{* * *}$ \\
& $(-24.92)$ & $(-40.52)$ \\
\hline \multirow{2}{*}{ Intermediate } & $-1.157^{* * *}$ & $-0.120^{* * *}$ \\
& $(-15.63)$ & $(-24.07)$ \\
\hline \multirow{2}{*}{ Higher } & $0.362^{* * *}$ & $0.059^{* * *}$ \\
& $(7.00)$ & $(6.37)$ \\
\hline \multirow{2}{*}{ Married } & $-0.443^{* * *}$ & $-0.072^{* * *}$ \\
& $(-9.69)$ & $(-8.93)$ \\
\hline \multirow{2}{*}{ SC } & -0.014 & -0.002 \\
& $(-1.37)$ & $(-1.37)$ \\
\hline \multirow{2}{*}{ Joint } & $-0.356^{* * *}$ & $-0.058^{* * *}$ \\
Sindh & $(-3.95)$ & $(-3.60)$ \\
\hline \multirow{2}{*}{ KPK } & $-0.973^{* * *}$ & $-0.119^{* * *}$ \\
& $(-27.92)$ & $(-34.01)$ \\
\hline \multirow{2}{*}{ Baluchistan } & $-1.328^{* * *}$ & $-0.158^{* * *}$ \\
& $(-35.48)$ & $(-44.65)$ \\
\hline \multirow{2}{*}{ Loglikelihood } & $-1.977^{* * *}$ & $-0.182^{* * *}$ \\
\hline R-squared & $(-35.04)$ & $(-60.76)$ \\
\hline Note: ****** ${ }^{*}$ denotes the significance at $1 \%, 5 \%$, and $10 \%$ respectively. () represents \\
t-values.
\end{tabular}

Estimates of Determinants of Participation of Women to the Unpaid Household Work

Results of logit model of women's participation to the unpaid household work are given in Table 4 . It has been observed that age is positively, and age square is negatively and significantly related with women's participation to the unpaid household work. This is because of the fact that women have more burden of household chores at the middle age as compared to the younger and old age. The regression coefficients of all the educational categories are negative and statistically significant for household. This implies that educated women have a lower probability of participation to the unpaid household work to that of women having no formal education, Kedir and Rogers (2018). One reason of this may be that she prefers paid market work over the unpaid household work with the increase in level of education. Another reason of this may be that she becomes more expert in doing the household chores and thus participated less.

The marital status has a positive and statistically significant relation with the unpaid household work. This means that married women take more household chores as compared to the unmarried women, Singh and Pattanaik (2019). The 
coefficients of number of small children and joint family system are negative but statistically insignificant.

Women from Sindh and Baluchistan have a positive and insignificant influence on household work participation. However, women from the KPK have a higher probability of doing household chores as compared to the women from the Punjab.

Table 4

Estimates of Determinants of Women's Participation to the Unpaid Household

Work

\begin{tabular}{|c|c|c|}
\hline Explanatory Variables & $\begin{array}{c}\text { Coefficients and } \\
\text { t-values }\end{array}$ & Marginal Effects \\
\hline Constant & $\begin{array}{c}3.624^{* * *} \\
(5.40)\end{array}$ & \\
\hline Age & $\begin{array}{c}0.067^{* *} \\
(2.10)\end{array}$ & $\begin{array}{c}0.000^{* *} \\
(2.12)\end{array}$ \\
\hline Age square & $\begin{array}{c}-0.001^{* * *} \\
(-2.97)\end{array}$ & $\begin{array}{c}-7.90 \mathrm{e}-06^{* * *} \\
(-3.02)\end{array}$ \\
\hline Primary & $\begin{array}{l}-0.142 \\
(-0.70)\end{array}$ & $\begin{array}{l}-0.001 \\
(-0.67)\end{array}$ \\
\hline Middle & $\begin{array}{c}-0.544^{* *} \\
(-2.23)\end{array}$ & $\begin{array}{l}-0.004^{*} \\
(-1.79)\end{array}$ \\
\hline Matric & $\begin{array}{c}-1.044^{* * *} \\
(-5.41)\end{array}$ & $\begin{array}{c}-0.011^{* * *} \\
(-3.73)\end{array}$ \\
\hline Intermediate & $\begin{array}{c}-1.678^{* * *} \\
(-7.98)\end{array}$ & $\begin{array}{c}-0.025^{* * *} \\
(-4.33)\end{array}$ \\
\hline Higher & $\begin{array}{c}-0.864^{* * *} \\
(-2.73)\end{array}$ & $\begin{array}{l}-0.008^{* *} \\
-1.90\end{array}$ \\
\hline Married & $\begin{array}{l}1.085^{* * *} \\
(5.53)\end{array}$ & $\begin{array}{c}0.010^{* * *} \\
(3.91)\end{array}$ \\
\hline SC & $\begin{array}{l}-0.055 \\
(-1.13)\end{array}$ & $\begin{array}{l}-0.000 \\
(-1.14)\end{array}$ \\
\hline JOINT & $\begin{array}{l}-0.058 \\
(-0.12)\end{array}$ & $\begin{array}{l}-0.000 \\
(-0.13)\end{array}$ \\
\hline Sindh & $\begin{array}{l}0.259 \\
(1.44)\end{array}$ & $\begin{array}{l}0.002 \\
(1.55)\end{array}$ \\
\hline KPK & $\begin{array}{c}0.412^{* * *} \\
(2.35)\end{array}$ & $\begin{array}{l}0.002^{* * *} \\
(2.57)\end{array}$ \\
\hline Baluchistan & $\begin{array}{l}0.102 \\
(0.47)\end{array}$ & $\begin{array}{l}0.001 \\
(0.48)\end{array}$ \\
\hline Loglikelihood & -1421.9998 & \\
\hline R-squared & 0.048 & \\
\hline
\end{tabular}

Note: ${ }^{* * *}, * *, *$ denotes the significance at $1 \%, 5 \%$, and $10 \%$ respectively. () represents t-values. 


\section{Conclusion}

In this study, we have explored the determinants, which explained behavior of women toward paid labor market work and unpaid household work. The study has concluded that there are number of factors that affect and shape the behavior of women's participation. The main finding of our study is that highly educated women have a higher probability of participation in paid labor market to that of women having no formal education. Women that are married, living in joint family and belonging to Sindh, KPK, and Baluchistan have a lower probability of participation to the paid labor market work as compared to the women that are unmarried, living in nuclear family and belonging to Punjab.

However, for unpaid household work, it has been observed that educated women have lower probability of participation to the household chores to that of women with no formal education. Women that are married and belonging to KPK possess higher probability of participation to the unpaid household work.

Based on the findings of the study, it is the need of time to carefully formulate policies by considering the proper analysis of the filed data related to the women employment. Government has to take steps for the improvement of education, provision of job facilities and childcare centers for women working in labor market. The lower rate of labor force participation of educated women is reflection of the fact of inadequate employment opportunities in labor market. The government has to take special measures for the provision of employment opportunities in labor market, so that women play their positive role in raising the standard of living of the household and the economy. As far the unpaid household work is concerned, the value of unpaid work of women in making home heaven should be recognized at the national and academic level. So that the common concept of our society that unpaid household work is inferior to that of paid market work is removed. 


\section{References}

Álvarez, B., \& Miles, D. (2003). Gender effect on housework allocation: Evidence from Spanish two-earner couples. Journal of Population Economics, 16(2), 227-242.

Batool, S. A., Tabassum, A., \& Saghir, S. (2019). Dynamics of Female Labor Force Participation in Pakistan. Pakistan Journal of Social Sciences (PJSS), 39(3), 751-762.

Benería, L., Berik, G., \& Floro, M. (2015). Gender, development and globalization: Economics as if all people mattered: Routledge.

Bianchi, S. M., Milkie, M. A., Sayer, L. C., \& Robinson, J. P. (2000). Is anyone doing the housework? Trends in the gender division of household labor. Social forces, 79(1), 191-228.

Bloemen, H. G., Pasqua, S., \& Stancanelli, E. G. (2010). An empirical analysis of the time allocation of Italian couples: are they responsive? Review of Economics of the Household, 8(3), 345-369.

Bloemen, H. G., \& Stancanelli, E. G. (2014). Market hours, household work, child care, and wage rates of partners: an empirical analysis. Review of Economics of the Household, 12(1), 51-81.

Che, G. N., \& Sundjo, F. (2018). Determinants of female labour force participation in Cameroon. International Journal of Applied Economics, Finance and Accounting, 3(2), 88103.

Chishti, S., Lodhi, A., \& Rashid, S. (1989). Female Labour Participation Behaviour: A Case Study of Karachi. Pakistan Journal of Applied Economics, 8(2), 157-165.

Dong, X. y., \& An, X. (2015). Gender Patterns and Value of Unpaid Care Work: Findings From C hina's First Large-Scale Time Use Survey. Review of Income and Wealth, 61(3), 540-560.

Ejaz, M. (2007). Determinants of female labor force participation in Pakistan an empirical analysis of PSLM (2004-05) micro data. The Lahore Journal of Economics, 12(S), 203-235.

Evenson, R. E. (1978). Time allocation in rural Philippine households. American Journal of Agricultural Economics, 60(2), 322-330.

Faridi, M. Z., Chaudhry, I. S., \& Basit, A. (2009). An Analysis of the Determinants of Male Labor Force Participation and Employment Status in Pakistan: The Case of Bahawalpur District. Pakistan Journal of Social Sciences (PJSS), 29(2). 
Gimenez-Nadal, J. I., \& Molina, J. A. (2013). Parents' education as a determinant of educational childcare time. Journal of Population Economics, 26(2), 719-749.

Hafeez, A., \& Ahmed, E. (2002). Factors determining the labor force participation decision of educated married women in a district of Punjab:Pakistan Economic and Social Review, no 1, 75-88.

Hallberg, D., \& Klevmarken, A. (2003). Time for children: A study of parent's time allocation. Journal of Population Economics, 16(2), 205-226.

Hosney, S. H. (2016). Factors influencing female labor force participation in Egypt and Germany: A comparative study (NO 826). SOEP Papers on Multidisciplinary Panel Data Research.

Hussain, M., Anwar, S., \& Huang, S. (2016). Socioeconomic and demographic factors affecting labor force participation in Pakistan. Journal of Sustainable Development, 9(4), 70-79.

Kanwal, W., Rizwan Ahmad, H., Arshed, N., \& Gulzar, M. (2019). Labor supply and demographics: A case of Pakistan. Journal of Labor and Society, 22(2), 491-508.

Kedir, A. M., \& Rodgers, P. (2018). Household survey evidence on domestic workers in Ethiopia. The Service Industries Journal, 38(11-12), 824-840.

Kes, A., \& Swaminathan, H. (2006). Gender and time poverty in sub-Saharan Africa. Gender, time use, and poverty in sub-Saharan Africa, 13.

Khandker, S. R. (1988). Determinants of women's time allocation in rural Bangladesh. Economic Development and Cultural Change, 37(1), 111-126.

Kozel, V., \& Alderman, H. (1990). Factors determining work participation and labour supply decisions in Pakistan's urban areas. The Pakistan Development Review, 1-17.

Singh, P., \& Pattanaik, F. (2019). Economic status of women in India: paradox of paidunpaid work and poverty. International Journal of Social Economics, 46(3), 410-428.

Sultana, N., Nazli, H., Malik, S. J., \& Kazi, S. (1994). Determinants of Female Time Allocation in Selected Districts of Rural Pakistan [with Comments]. The Pakistan Development Review, 33(4), 1141-1153.

Zaheer Khan, M., \& Hafeez, A. (2017). Economic activities and unmarried labour. Economic research-Ekonomska istraživanja, 30(1), 985-991. 